\title{
Kavitasyon Gösteren COVID-19 Pnömonisi
}

\section{COVID-19 Pneumonia with Cavitation}

\author{
Ug̃ur KESIMAL'(İD), Șenay ÖZTÜRK DURMAZ²(ID) \\ ${ }^{1}$ Recep Tayyip Erdog̃an Üniversitesi Tıp Fakültesi, Radyoloji Anabilim Dalı, Rize, Türkiye \\ ${ }^{2}$ Kepez Devlet Hastanesi, İnfeksiyon Hastalıkları ve Klinik Mikrobiyoloji Klinig̃i, Antalya, Türkiye
}

Makale atıfi: Kesimal U, Öztürk Durmaz ş. Kavitasyon gösteren COVID-19 pnömonisi. FLORA 2021;26(3):560-4.

\begin{abstract}
ÖZ
Dünya Sağılk Örgütü, 11 Şubat 2020'de viral pnömoniye yol açan yeni tip bir koronavirüsün neden olduğu hastalığı resmen "Coronavirus Disease 2019 (COVID-19)" olarak adlandırılmıştır. Hastalığın tipik bilgisayarlı tomografi bulguları her iki akciğerde bulunan buzlu cam dansitesinde infiltrasyonlardır. Atipik bulgular arasında ise akciğer kavitasyonu ve plevral efüzyon bulunmaktadır. Kırk üç yaşında kadın hasta, üç gündür olan kuru öksürük, yorgunluk, iştahsızlık ve eklem ağrısı şikayetleriyle acil servise başvurdu. Başvuru anındaki akciğer tomografisinde bilateral periferik yerleşimli multisegmenter buzlu cam dansitesinde infiltrasyonları mevcuttu. Kombine nazofaringeal sürüntü alınan hastaya favipiravir ve hidroksiklorokin tedavisi başlandı ve hasta 14 gün izolasyon önerisi ile evine gönderildi. Aynı gün yapılan gerçek zamanlı ters transkriptaz polimeraz zincir reaksiyonu (rRT-PCR) testi ile hastanın COVID19 olduğu doğrulandı. ilk başvurudan beş gün sonra şikayetlerinde artış ile tekrar hastaneye başvuran hastanın oksijen satürasyonu $\left(\mathrm{SpO}_{2}\right) \% 90$ saptandı ve hasta, tedavisinin devamı için hastaneye yatııldı. Hastaneye yatışını beşinci gününde kliniğinin düzelmesi üzerine hasta taburcu edildi. iki hafta sonra genel durumunda bozulma, ateş, solunum sıkıntısı ile acil servise getirilen hastanın çekilen akciğer tomografisinde sağ akciğer alt lobda kavitasyon alanı barındıran nekrotizan pnömoni sahası izlendi. Hasta beş gün yoğun bakım ünitesinde takip edildikten sonra ateşinin düşmesi, solunum sıkıntısı, öksürüğünün ve C-reaktif protein (CRP) değerinin gerilemesi üzerine beş gün de COVID servisinde izlenerek taburcu edildi. COVID-19 pnömonisine bağlı akciğer kavitasyonu nadirdir ve vakaların çoğu kendi kendini sınırlar. Hastanın son rRT-PCR testi negatif gelse dahi akciğerdeki kaviter lezyon düşük seviyede de olsa bulaşıcılığın devamını sağlayabilir. Bu yüzden bu tür hastalarda tedavi ve izolasyon süresinin uzatılması düşünülmelidir.
\end{abstract}

Anahtar Kelimeler: COVID-19; Kavitasyon; Nekrotizan pnömoni 


\title{
ABSTRACT \\ COVID-19 Pneumonia with Cavitation
}

\author{
Ug̃ur KESIMAL', Șenay ÖZTÜRK DURMAZ²
}

\author{
${ }^{1}$ Department of Radiology, Recep Tayyip Erdog̃an University Faculty of Medicine, Rize, Turkey \\ ${ }^{2}$ Clinic of Infectious Diseases and Clinical Microbiology, Kepez State Hospital, Antalya, Turkey
}

The World Health Organization officially named the disease as Coronavirus Disease 2019 (COVID-19), which was caused by a new type of coronavirus that leads to viral pneumonia on 11 February 2020. Typical computed tomography findings of the disease are ground-glass infiltrations in both lungs. Atypical findings include lung cavitation and pleural effusion. A 43-year-old female patient was admitted to the emergency room with complaints of dry cough, fatigue, and joint pain for three days. Bilateral peripherally localized multisegmented ground-glass infiltrates were present in the first thorax tomography. A combined nasopharyngeal swab was taken from the patient and favipiravir and hydroxychloroquine treatment was initiated and she was sent home with the recommendation of isolation for 14 days. Real-time reverse transcriptase-polymerase chain reaction ( $r R T-P C R)$ test performed on the same day and confirmed COVID-19 diagnosis. She was admitted to the hospital again with an increase in complaints five days after the first presentation and her oxygen saturation $\left(\mathrm{SpO}_{2}\right)$ was found to be $90 \%$. On the fifth day of her hospitalization, the patient was discharged because of clinical improvement. Two weeks later, she was brought to the emergency room with deterioration in her general condition. On thorax tomography of the patient, an area of necrotizing pneumonia with cavitation in the lower lobe of the right lung was observed. The patient was followed up in the intensive care unit for five days. After being followed up in the COVID service for five days, she was discharged because her respiratory distress, cough and C-reactive protein (CRP) was decreased. Lung cavitation due to COVID-19 pneumonia is rare, and most cases are self-limiting. Although the last rRT-PCR test of the patient is negative, the cavitary lesion in the lung can maintain contagiousness even if it is at a low level. Therefore, the extension of treatment and isolation time should be considered in such patients.

Key Words: COVID-19; Cavitation; Necrotizing pneumonia

\section{GiRiș}

Dünya Sağllk Örgütü 11 Subat 2020'de, ilk olarak Aralı 2019'da Cin'in Wuhan sehrinde görülen ve viral pnömoniye yol açan yeni tip bir koronavirüsün neden olduğu hastalığı resmen COVID-19 (Coronavirus Disease-19) olarak adlandırdı. Hastalı 200'den fazla ülkeyi kapsayan küresel bir salgın haline geldi. Ates, öksürük, nefes darlığı gibi solunum yolu belirtileri ile ortaya cıkan COVID-19'da vakaların \%80'inin hafif semptomlar gösterdiği ve \%20'sinin de hastaneye yatarak tedavi edilmesinin gerektiği saptanmıștır. Hipertansiyon, diyabetes mellitus ve kronik solunum yolu hastalıklarına sahip ve 60 yas üzerindeki kișilerde hastalığın daha ağır seyrettiği gözlenmiștir. Cin'de yapılmıs kapsamlı bir calıșmada diabetik hastaların COVID-19'a bağlı ölüm oranları \%7.3 olarak bulunmuștur ${ }^{[1,2]}$. Ülkemizde COVID-19'a bağlı pnömoni gelișme oranı \%5.6 olarak saptanmıstır, toplam vaka sayısı Haziran 2021 itibariyla 5.370.000'lere ulașmıștır. Gerçek zamanl ters transkriptaz polimeraz zincir reaksiyo- nu (rRT-PCR) ile yapilan COVID-19 nükleik asit testlerinin, kesin tanı konulmadan önce birkaç kez negatif sonuc verebileceği literatürde belirtilmektedir ${ }^{[3]}$. Hastalığın tipik bilgisayarlı tomografi (BT) bulguları her iki akciğerde daha cok alt lob subplevral bölgelerinde bulunan buzlu cam opasiteleri ve konsolidasyonlardır ${ }^{[4]}$. Atipik bulgular arasında ise tipik bulguların yokluğu ve izole lober veya segmental konsolidasyon, tomurcuklanma paterni gösteren santrilobüler nodüller, akciğer kavitasyonu ve plevral efüzyon bulunur. Nekroz, ağır seyirli pnömoninin bir komplikasyonudur. Akciğer parankiminde doku nekrozu sonucu bir mm'den kalın, inflamatuvar veya neoplastik elemanlardan oluşan duvarı olan, hava veya siviyla dolu bosluklara kavite denir ${ }^{[5]}$. Bu vaka sunumunda nadir ve atipik bulgulardan olan pulmoner kavite geliștiren bir COVID-19 vakasını sunuyoruz.

\section{OLGU SUNUMU}

Kırk üc yașında kadın hasta, üc gündür olan kuru öksürük, yorgunluk, iștahsızlık ve eklem ağrısı sikayetleriyla acil servis COVID-19 değer- 
lendirme alanına 05.09.2020 tarihinde bașvurdu. Hastanın hipertansiyon, tüberküloz, sigara kullanım öyküsü yoktu. Ancak üc yıldır diyabetes mellitus için oral antidiabetik tedavi almaktaydi. Yapılan fizik muayenesinde ates $37.4^{\circ} \mathrm{C}$, kan basınc1 120/66 mmHg, nabız $101 \mathrm{atım} / \mathrm{dk}$, oda havasinda oksijen satürasyonu $\left(\mathrm{SpO}_{2}\right)$ \%95 ölçüldui. Akciğer oskültasyonunda her iki tarafta solunum sesleri kabalașmıștı. Kan tahlillerinde C-reaktif protein (CRP) $147 \mathrm{mg} / \mathrm{dL}$ (0-5), lökosit say1s1 $7.6 \times 10^{3} / \mu \mathrm{L}$ (4.4-12.6), kreatinin $0.9 \mathrm{mg} /$ dL (0.5-1.1), eGFR $78 \mathrm{~mL} / \mathrm{dk} / 1.73 \mathrm{~m}^{2}$, glukoz

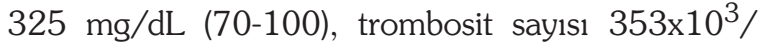
$\mu \mathrm{L}$ (173-390), D-dimer $145 \mathrm{ng} / \mathrm{mL}$ (0-240) olarak saptandı. Basvuru anındaki akciğer tomografisinde bilateral periferik yerleșimli multisegmenter buzlu cam dansitesinde infiltrasyonları mevcuttu (Sekil 1). Kombine nazofaringeal sürüntü alınan hastaya favipiravir 2x1600 mg ilk gün, 2x600 mg dört gün ve hidroksiklorokin $2 \times 200 \mathrm{mg}$ bes gün olacak sekilde tedavisi bașlandı ve hasta 14 gün izolasyon önerisi ile evine gönderildi. Aynı gün yapılan rRT-PCR testi ile hastanın COVID-19 olduğu doğrulandi. İlk bașvurudan beș gün sonra (11.09.2020) öksürük miktarında artıs, kırgınlık, bulantı ve kusma sikayetiyle tekrar hastaneye bașuran hastanın ateși $37.6^{\circ} \mathrm{C}$, kan basıncı 130/74 mmHg, nabız $120 \mathrm{atım} / \mathrm{dk}$, oda havasında $\mathrm{SpO}_{2} \% 90$ saptand. Akciğer oskültasyonunda bilateral alt zonlarda raller mevcuttu. Yapilan kan tahlillerinde CRP $155 \mathrm{mg} / \mathrm{dL}$, kreatinin 1.26 $\mathrm{mg} / \mathrm{dL}$, eGFR $52 \mathrm{~mL} / \mathrm{dk} / 1.73 \mathrm{~m}^{2}$, lökosit say1s1 $10.8 \times 10^{3} / \mu \mathrm{L}$ ve D-dimer $557 \mathrm{ng} / \mathrm{mL}$ olarak bulundu. Hastanın COVID servisine yatıșı yapıldı ve hastaya levofloksasin $1 \times 500 \mathrm{mg}$ oral ve enoksaparin sodyum $0.4 \mathrm{~mL}$ subkutan olacak sekilde tedavi bașlandı. Yatıșının beșinci gününde hastanın solunum sıkıntısı ve öksürüğü geriledi ve oda havasında $\mathrm{SpO}_{2}$ \%97'ye cıktı, CRP'sinin de 32 mg/dL'ye kadar gerilemesi üzerine levofloksasin tedavisini 10 güne tamamlaması önerilerek hasta taburcu edildi. Hasta taburculuğundan iki hafta sonra (29.09.2020) genel durumunda bozulma, ates, solunum sıkıntısı ile acil servise getirildi, oda havasında $\mathrm{SpO}_{2} \% 88$, ates $38^{\circ} \mathrm{C}$, lökosit sayısı $19.2 \times 10^{3} / \mu \mathrm{L}$, CRP $206 \mathrm{mg} / \mathrm{dL}$, glukoz $531 \mathrm{mg} /$ dl, kreatinin $1 \mathrm{mg} / \mathrm{dL}$, eGFR $69 \mathrm{~mL} / \mathrm{dk} / 1.73 \mathrm{~m}^{2}$ saptand. Hastanın cekilen akciğer tomografisinde her iki akciğer alt loblarda hava bronkogramları içeren konsolide alanlar, her iki akciğer alt lob

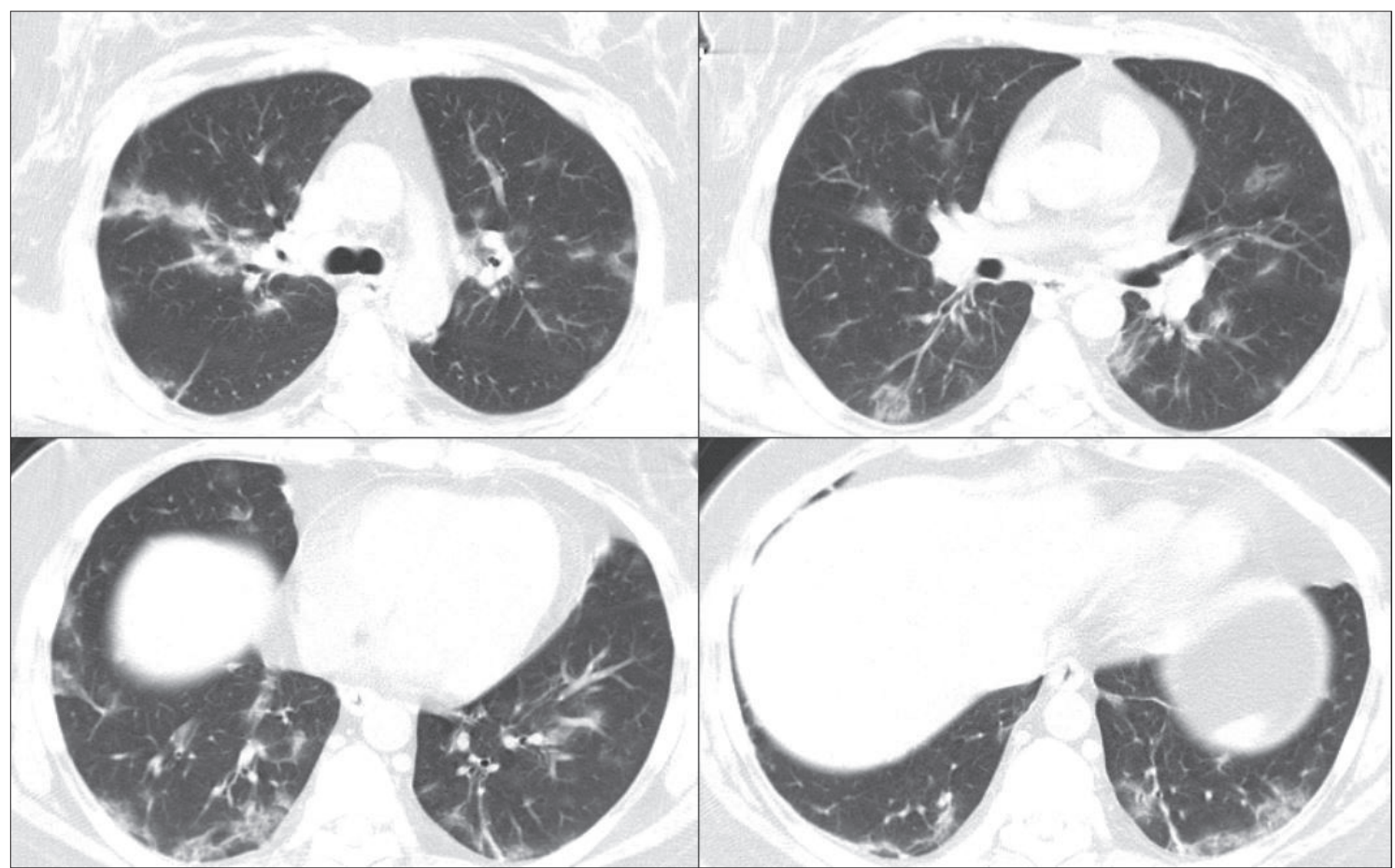

Şekil 1. Kontrastsız akciğer bilgisayarlı tomografisinde her iki akciğerde tüm loblarda multisegmenter yerleşimli periferik dağılım gösteren buzlu cam dansitesinde pnömonik infiltrasyon sahaları izleniyor. 


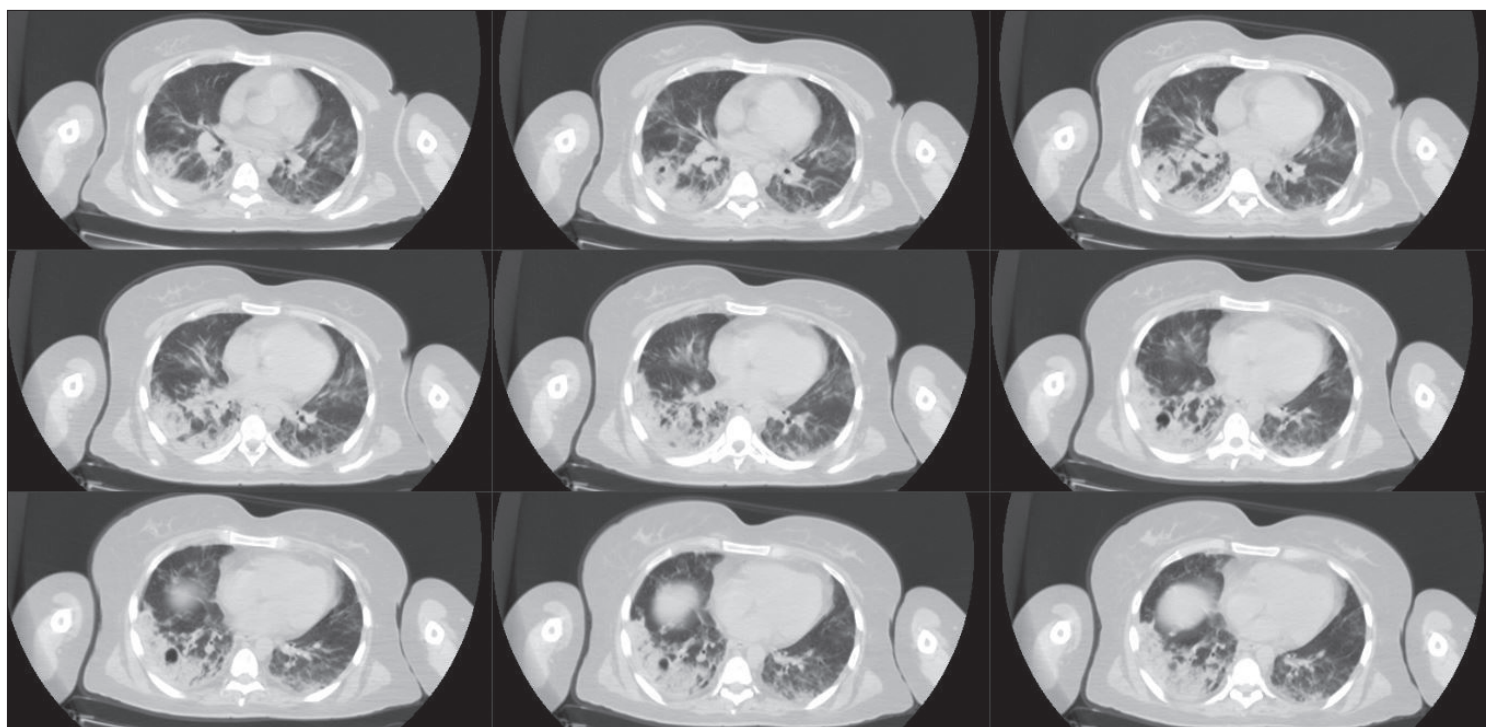

Şekil 2. Hastanın semptom başlangııından yaklaşık 23 gün sonrasında çekilen toraks tomografisinde sağ akciğer alt lobda kavitasyon alanları barındıran nekrotizan pnömoni bulguları görülmektedir.

posteriorlarda daha yaygin buzlu cam dansitesinde infiltrasyonlar ve sağ akciğer alt lob posterior segmentte 22 ve 9 mm'lik iki kavitasyon alanı barındıran nekrotizan pnömoni sahası izlenmiștir (Șekil 2). Yoğun bakıma yatırılan hastaya meropenem $3 \times 1$ gr, prednol $1 \times 32 \mathrm{mg}, \mathrm{C}$ vitamini $1 \times 3$ gr, klaritromisin $2 \times 500 \mathrm{mg}$, enoksaparin sodyum $0.6 \mathrm{~mL} 1 \times 1$ subkutan tedavi bassland. Burada COVID-19 açısından yapilan kombine sürüntü rRT-PCR testi negatif saptand. Hastanin balgam kültüründe patojen mikroorganizma üremesi olmadi. İdrar kültüründe ve kan kültürlerinde üreme saptanmayan hasta bes gün yoğun bakımda takip edildikten sonra ateșinin düșmesi, solunum sıkınt1sının, öksürüğünün ve CRP'nin gerilemesi üzerine bes gün de COVID-19 servisinde takip edilerek taburcu edildi.

\section{TARTIŞMA}

Bir tür RNA virüsü olan koronavirüsler, insanlarda üst ve alt solunum yollarinda hastal1ğa neden olabilmektedir. Siddetli akut solunum sendromu koronavirüs 2 (SARS-CoV-2)'nin neden olduğu ve oldukça bulașıcı bir hastalık olan $\mathrm{CO}$ VID-19 ile iliskili erken ve gec komplikasyonlar halen tam olarak bilinmemektedir. Hastalığın en sık belirtileri arasında ates, öksürük, yorgunluk ve nefes darlığı bulunur. Bununla birlikte en sık eslik eden komorbid durumlar ise hipertansiyon, diyabetes mellitus, kardiyovasküler hastalıklar ve solu- num sistemi hastalıklarıdır [6]. COVID-19'un tipik BT görüntüleme özellikleri temel olarak özellikle alt loblarda buzlu cam ve konsolidasyona ait pulmoner opasiteleri içerir. Bununla birlikte kavitasyon, lenfadenopati ve plevral efüzyonun olmaması önemli bulgularındandır. Klinisyenler, COVID-19'un BT bulgularının farkinda olmalı ve tam iyileșmeyi sağlamak için COVID-19'lu hastalarının uygun takibini düzenlemelidir. COVID-19'un nadir görülen bulgularından olan kavitasyonu sunduğumuz bu olguda antibiyotik kullanımına gec bașlanmış ve ilk tedavi süresi oldukça kısa tutulmuștu. $\mathrm{Bu}$ olguda olduğu gibi diyabetes mellitus ve benzeri komorbid durumu olan ve tekrarlayan hastane bassurusu olan hastalarda erken taburculuk düsüinülmemelidir. COVID-19 pnömonisine bağlı akciğer kavitasyonu nadirdir ve vakaların coğu kendi kendini sınırlar ${ }^{[7]}$. SARS-CoV-2 virüsü bronșiyol mukozasinda veya alveolar epitel hücrelerinde coğalabilir, bu da pulmoner parankimin ve alveollerin interstisyel dokusunun, interlobüler septanın ve periasiner mikrovasküler ağın hasarlanmasına neden olur. COVID-19 pnömonisinde kavitasyonun tam mekanizması bilinmemekle birlikte, otopsi raporlarına göre virüsün neden olduğu yaygın alveolar hasar, alveoler hemoraji ve parankimal hücrelerin nekrozu ile ilișkili olabileceği belirtilmektedir ${ }^{[8,9]}$. Coğu tedavi edilen viral pnömonide, akciğer lezyonları kademeli olarak absorbe olur ve 
dağılır, nadir siddetli olgularda fibrozis gelișebilir. COVID-19 için hastaların iyileșme dönemindeki radyolojik imaj değișikliği daha fazla gözlem ve araștırma gerektirmektedir. Hastanın son rRT-PCR testi negatif gelse dahi akciğerdeki kaviter lezyon düșük seviyede de olsa bulașıcılığın devamını sağlayabilir. Bu yüzden bu tür hastalarda tedavi ve izolasyon süresinin uzatılması düșünülmelidir.

Sonuc olarak, siddetli COVID-19 akciğer hastalığı olan hastalarda akciğerde kavitasyonun olușabileceği, hemoptizi, pnömotoraks gibi sekonder komplikasyonların gelișebileceği ve bu durumların kötü prognostik sonuçları olabileceği akıldan çıkarılmamalıdır. Direkt grafilerde kavitasyon süphesi varlığında erken kesitsel görüntüleme düșünülmeli ve kavitasyon gelișme riskini artırabilecek nedenlere yönelik kapsamlı bir araștırma yapılması gerektiği kanaatindeyiz.

\section{ÇIKAR ÇATIŞMASI}

Yazarlar bu makale ile ilgili herhangi bir c1kar çatıșması bildirmemișlerdir.

\section{YAZAR KATKISI}

Anafikir/Planlama: UK

Analiz/Yorum: UK, ŞÖD

Veri sağlama: UK, ȘÖD

Yazım: UK, ȘÖD

Gözden Geçirme ve Düzeltme: UK, ȘÖD

Onaylama: UK, ȘÖD

\section{KAYNAKLAR}

1. Günal Ö, Türe E, Bayburtlu M, Arslan U, Demirağ MD. Evaluation of Patients Diagnosed with COVID-19 in Terms of Risk Factors. Mikrobiyol Bul 2020;54(4):575-82.
2. Guan WJ, Ni ZY, Hu Y, Liang WH, Ou CQ, et al. Clinical Characteristics of Coronavirus Disease 2019 in China. N Engl J Med 2020;382(18):1708-20.

3. Chinese Society of Radiology. Radiological diagnosis of new coronavirus infected pneumonitis: expert recommendation from the Chinese Society of Radiology (First edition). Chin J Radiol 2020;54:279-85.

4. Ye Z, Zhang $Y$, Wang $Y$, Huang $Z$, Song B. Chest CT manifestations of new coronavirus disease 2019 (COVID-19): a pictorial review. Eur Radiol 2020;30(8):4381-89.

5. Chatha N, Fortin D, Bosma KJ. Management of necrotizing pneumonia and pulmonary gangrene: a case series and review of the literature. Can Respir J 2014;21(4):239-45.

6. Yang J, Zheng Y, Gou X, Pu K, Chen Z. Prevalence of comorbidities in the novel Wuhan coronavirus (COVID-19) infection: a systematic review and meta-analysis. Int J of Infect Dis 2020;94:91-5.

7. Chen Y, Chen W, Zhou J, Sun C, Lei Y. Large pulmonary cavity in COVID-19 cured patient case report. Ann Palliat Med 2020;9:5-452.

8. Menter T, Haslbauer JD, Nienhold R, Savic S, Hopfer $H$. Postmortem examination of COVID-19 patients reveals diffuse alveolar damage with severe capillary congestion and variegated findings in lungs and other organs suggesting vascular dysfunction. Histopathology 2020;77(2):198209.

9. Yao XH, Li TY, He ZC, Ping YF, Liu HW. A pathological report of three COVID-19 cases by minimal invasive autopsies. Zhonghua Bing Li Xue Za Zhi 2020;49(5):411-7.

\section{Yazıșma Adresi/Address for Correspondence Dr. Uğur KESIMAL \\ Recep Tayyip Erdoğan U̇niversitesi Tıp Fakültesi, Radyoloji Anabilim Dalı, Rize-Türkiye \\ E-posta: ugur_kesimal@hotmail.com}

